\title{
Differentiation into various cell lineages of adipose derived stem cells
}

\author{
Woo Jung Ho and Hea-Jo Yoon* \\ Stem Cell Research Center, Apgujeong Miracle Clinic, South Korea
}

\begin{abstract}
Adipose derived stem cells (ASC) can be extracted easily in large quantities with low mortality. ASC have a potential of differentiation toward mesodermal stem cell lineages such as adipogenic, chondrogenic, osteogenic and myogenic pathways and ectodermal stem cell lineage such as neuronal pathway. ASC differentiation may be achieved with specific induction cocktails in culture medium. ASC and differentiated cells could have a pivotal role in fat grafting reconstruction, bone defect healing, muscle reconstruction procedure, and recovery from central-peripheral nerve injury.
\end{abstract}

Abbreviations: ASC: Adipose Derived Stem Cells; IBMX: IsobutylMethyl Xanthine; C/EBP: CCAAT Enhancer Binding Protein; IL: Interleukin; TGF: Transforming Growth Factor; TNF: Tumor Necrosis Factor; BMP: Bone Morphogenetic Protein

\section{Introduction}

Adipose derived stem cells (ASC) can be easily and repeatedly extracted from liposuction and can be obtained in large quantities with minimal discomfort. In addition, ASC can also proliferate and differentiate well, have multi-lineage differentiating potential, adhere well to plastic surface, and maintain the characteristics of stem cells in all age groups compared to adult stem cells from other sources [1]. It can be differentiated into most mesenchymal cells such as adipogenic, chondrogenic, osteogenic and myogenic cells and cells of the neural ectodermal lineage. Zuk et al. obtained lipid tissue by liposuction, treated with collagenase, centrifuged and separated into the upper fat cell layer and the lower stromal vascular fraction. They induced adipogenic, chondrogenic, osteogenic, myogenic, and neurogenic differentiation pathways using lineage specific induction agents such as dexamethasone, isobutyl-methyl xanthine (IBMX), insulin, 1.25-dihydroxyvitamine D3, and ascorbate [2]. This mini review highlights the differentiation of ASC into various mesenchymal lineages and neuronal differentiation under in vitro and in vivo conditions and clinical application of ASC.

\section{Adipogenesis}

Fat transfer can be useful for reconstruction of soft-tissue defects due to trauma, surgical resection, or cosmetic procedures such as treatment of wrinkles. ASC-enriched fat grafting can enhance fat graft survival rate by reducing reabsorption of fatty tissue transplanted [3]. The standard induction cocktail for adipocytes differentiation is composed of IBMX, dexamethasone, insulin, and indomethacin [4]. Dexamethasone and IBMX induce differentiation of ASC into adipocytes by increasing expression of CCAAT enhancer binding protein $(\mathrm{C} / \mathrm{EBP})$ and intracellular cAMP, respectively $[5,6]$. Adipocyte differentiation can be easily confirmed by the Oil Red $\mathrm{O}$ staining of lipid vacuoles [7]. In contrast, high level of retinoids, interleukin (IL) -1 , IL-2, transforming growth factor (TGF) $\beta$ and tumor necrosis factor (TNF) a inhibit adipocyte differentiation [8]. Adipogenesis and angiogenesis are closely related, and the development of fat mass growth and microcirculation occurs together during fetal development [9]. Addition of factors involved in angiogenesis, such as vascular endothelial growth factors, fibroblast growth factor-2, platelet-derived growth factor $\mathrm{BB}$, increased angiogenesis in adipose tissue and improved adipose tissue growth in vivo murine tissue [10]. Vascularized adipose tissue using ASC can play an important role in tissue replacement procedures such as cosmetic, trauma, and cancerrelated reconstructive procedures.

\section{Chondrogenesis}

ASC can differentiate into cartilage. In vitro, high-density culture of ASCs induced by chondrogenic medium (supplementation with insulin, TGF $\beta$, and ascorbate-2-phosphate) resulted in increased expression of extracellular matrix proteins and formation of the cartilage compact nodule [2]. An in vivo animal experiment revealed that reconstitution ability of cultured ASCs on femoral defect was better than that of periosteum-derived stem cell or native mechanisms [11]. Treatment of ASC with bone morphogenetic protein (BMP)-7 for only 15 minutes proved to promote cartilage differentiation [12].

\section{Osteogenesis}

Lee et al. initiated ASC culture from the epididymal fat pad of Lewis rat and differentiated ASC into osteoblasts using bone induction factors [7]. Cells differentiated into osteoblasts were transplanted to Lewis rat subcutaneous tissues and in vivo bone formation was identified at 8 weeks. Differentiation into osteoblast was evidenced

${ }^{*}$ Correspondence to: Hea-Jo Yoon, Stem Cell Research Center, Apgujeong Miracle Clinic, Seoul, South Korea, Tel: 82-1588-7013; Fax: 82-2000-7822; E-mail: heajo7890@daum.net

Key words: adult stem cells, adipogenesis, cell differentiation, osteogenesis, neurogenesis

Received: February 04, 2019; Accepted: February 22, 2019; Published: February 26, 2019 
by Alizarin red staining of a calcified extracellular matrix and the immunohistochemical staining for osteocalcin [7]. Cowan et al. showed that $70-90 \%$ of critical-size mouse calvarial defects could be treated with implanted PLGA scaffolds seeded with ASC in 12 weeks [13]. Dexamethasone, $\beta$-glycerophosphate, ascorbic acid, and vitamin $\mathrm{D}$ can be used to promote the differentiation of stem cells into the osteogenic lineage $[7,14]$. As with the use of BMP-7 for chondrogenic differentiation, treatment of BMP-2 in ASC for 15 minutes can promote osteogenic differentiation [12].

\section{Myogenesis}

ASC cultures supplemented with desmin, myogenin, myogenic regulatory factor, and myosin heavy chain promote myogenesis [2]. However, the differentiation into myocytes takes more than 4 weeks, and it is the most difficult to differentiate among all the stem cell differentiation with low reproducibility [15]. Rodriguez et al. injected human ASC into the anterior tibialis of dystrophin-deficient mice as a model for Duchenne muscular dystrophy and observed that human dystrophin was expressed in the injected tibialis anterior of the mice at 6 months after administration [16]. In addition, dystrophin - positive cells were observed in the adjacent gastrocnemius muscle, suggesting human ASC migration to the surrounding muscle [16].

\section{Neurogenesis}

When ASC were cultured in no serum media with $\beta$-mercaptoethanol, new growth of cellular retraction and processes from the cell body were observed [2]. This change was associated with a concurrent increase in expression of neuronal markers such as NeuN, nestin and NSE [2]. ASC could differentiate into the neuronal and the glial pathways when valproic acid, butylated hydroxyanisole, insulin, and hydrocortisone were used as differentiation inducers [17]. Angiogenesis, enhanced immunosuppression, and an increase of the viability of endogenous neurons as well as direct cell replacement of stem cells might be involved in symptom improvement of the stroke patients [18]. Kim et al. reported that undifferentiated ASC and neuronal lineage cells derived from ASC promoted peripheral nerve regeneration (higher nerve conduction velocity) in rats undergoing nerve defect bridged by tubes made of the polycaprolactone [19].

\section{Conflicts of interest}

The authors declare that the research was conducted in the absence of any commercial or financial relationships that could be construed as a potential conflict of interest.

\section{References}

1. Guneta V, Tan NS, Chan SKJ, Tanavde V, Lim TC, et al. [2016] Comparative study of adipose-derived stem cells and bone marrow-derived stem cells in similar microenvironmental conditions. Exp Cell Res 348: 155-164. [Crossref]

2. Zuk PA, Zhu M, Ashjian P, De Ugarte DA, Huang JI, et al. (2002) Human adipose tissue is a source of multipotent stem cells. Mol Biol Cell 13: 4279-4295. [Crossref]
3. Kølle FT, Fischer-Nielsen A, Mathiasen AB, Elberg JJ, Oliveri RS, et al. [2013] Enrichment of autologous fat grafts with ex-vivo expanded adipose tissue-derived stem cells for graft survival: A randomised placebo-controlled trial. The Lancet 382: 11131120. [Crossref]

4. Thirumala S, Gimble JM, Devireddy RV (2010) Evaluation of methylcellulose and dimethyl sulfoxide as the cryoprotectants in a serum-free freezing media for cryopreservation of adipose-derived adult stem cells. Stem Cells Dev 19: 513-522. [Crossref]

5. Wu Z, Bucher N, Farmer SR (1996) Induction of peroxisome proliferator-activated receptor gamma during the conversion of $3 \mathrm{~T} 3$ fibroblasts into adipocytes is mediated by C/EBPbeta, C/EBPdelta, and glucocorticoids. Mol Cell Biol 16: 4128-4136. [Crossref]

6. Tang QQ, Jiang MS, Lane MD (1999) Repressive effect of Sp1 on the C/EBPalpha gene promoter: Role in adipocyte differentiation. Mol Cell Biol 19: 4855-4865. [Crossref]

7. Lee JA, Parrett BM, Conejero JA, Laser J, Chen J, et al. (2003) Biological alchemy: Engineering bone and fat from fat-derived stem cells. Ann Plast Surg 50: 610-617. [Crossref]

8. Boone C, Mourot J, Grégoire F, Remacle C (2000) The adipose conversion process Regulation by extracellular and intracellular factors. Reprod Nutr Dev 40: 325-358. [Crossref]

9. Crandall DL, Hausman GJ, Kral JG (1997) A review of the microcirculation of adipose tissue: Anatomic, metabolic, and angiogenic perspectives. Microcirculation 4: 211232. [Crossref]

10. Rophael JA, Craft RO, Palmer JA, Hussey AJ, Thomas GP, et al. (2007) Angiogenic growth factor synergism in a murine tissue engineering model of angiogenesis and adipogenesis. Am J Clin Pathol 171: 2048-2057. [Crossref]

11. Nathan S, Das De S, Thambyah A, Fen C, Goh J, et al. (2003) Cell-based therapy in the repair of osteochondral defects: A novel use for adipose tissue. Tissue Eng 9: 733744. [Crossref]

12. Knippenberg M, Helder M, Doulabi BZ, Wuisman P, Klein-Nulend J (2006) Osteogenesis versus chondrogenesis by BMP-2 and BMP-7 in adipose stem cells. Biochem Biophys Res Commun 342: 902-908. [Crossref]

13. Cowan CM, Shi YY, Aalami OO, Chou YF, Mari C, et al. (2004) Adipose-derived adult stromal cells heal critical-size mouse calvarial defects. Nat Biotechnol 22: 560567. [Crossref]

14. Zuk PA, Zhu M, Mizuno H, Huang J, Futrell JW, et al. (2001) Multilineage cells from human adipose tissue: Implications for cell-based therapies. Tissue Eng 7: 211-228. [Crossref]

15. Tholpady SS, Llull R, Ogle RC, Rubin JP, Futrell JW, et al. (2006) Adipose tissue: Stem cells and beyond. Clin Plast Surg 33: 55-62, vi. [Crossref]

16. Rodriguez AM, Pisani D, Dechesne CA, Turc-Carel C, Kurzenne JY, et al. (2005) Transplantation of a multipotent cell population from human adipose tissue induces dystrophin expression in the immunocompetent mdx mouse. $J$ Exp Med 201: 13971405. [Crossref]

17. Madhu V, Dighe AS, Cui Q, Deal DN (2016) Dual inhibition of activin/nodal/TGF-ß. and BMP signaling pathways by SB431542 and dorsomorphin induces neuronal differentiation of human adipose derived stem cells. Stem Cells Int 2016:1035374. [Crossref]

18. Hao L, Zou Z, Tian H, Zhang Y, Zhou H, et al. (2014) Stem cell-based therapies for ischemic stroke. Biomed Res Int 2014: 468748. [Crossref]

19. Kim DY, Choi YS, Kim SE, Lee JH, Kim SM, et al. (2014) In vivo effects of adipose-derived stem cells in inducing neuronal regeneration in Sprague-Dawley rats undergoing nerve defect bridged with polycaprolactone nanotubes. J Korean Med Sci 29: S183-S192. [Crossref]

Copyright: (C2019 Ho WJ. This is an open-access article distributed under the terms of the Creative Commons Attribution License, which permits unrestricted use, distribution, and reproduction in any medium, provided the original author and source are credited. 